\title{
Appendix
}

\section{TIMELINE OF IMPORTANT EVENTS}

$1850 \mathrm{~s}$

1920 s

1962

1966

1968

1997

1998

1999

2000

2001

2000-2005

2005

2005

2006

2007
First Dutch encounter with the border Iban

Iban pacification

Konfrontasi with Malaysia

The beginning of Soeharto's New Order regime

'Operation Destruction' and PARAKU uprooting

Commencement of the economic crisis in Indonesia

Collapse of Soeharto's authoritarian regime

De-facto regional autonomy in the border area

Initial ideas behind special autonomy in the border region emerge

Official implementation of regional autonomy

Cooperative (illegal) logging between local elites,

Malaysian entrepreneurs, and district government

Operation Everlasting Forest (central government

crackdown on illegal logging in the border region)

Central government presentation of border

development plans: large-scale plantations and

increased military control

Local lobbying for new border district formally initiated

'Border District' committee officially declared 